\title{
Reproducibility in cheminformatics and computational chemistry research: certainly we can do better than this
}

\author{
Gregory A Landrum \\ From 8th German Conference on Chemoinformatics: 26 CIC-Workshop \\ Goslar, Germany. 11-13 November 2012
}

According to the American Chemical Society's "Ethical Guidelines to Publication of Chemical Research":

An author's central obligation is to present an accurate and complete account of the research performed, absolutely avoiding deception, including the data collected or used, as well as an objective discussion of the significance of the research. Data are defined as information collected or used in generating research conclusions. The research report and the data collected should contain sufficient detail and reference to public sources of information to permit a trained professional to reproduce the experimental observations [1].

This presentation will explore some of the implications of this for the publication of new computational methods, do a quick survey of the current state of affairs in our literature, and make a few suggestions about how we can do better.

Published: 22 March 2013

\section{Reference}

1. [http://pubs.acs.org/userimages/ContentEditor/1218054468605/ethics.pdf].

Publish with ChemistryCentral and every scientist can read your work free of charge

"Open access provides opportunities to our colleagues in other parts of the globe, by allowing anyone to view the content free of charge."

W. Jeffery Hurst, The Hershey Company.

- available free of charge to the entire scientific community

- peer reviewed and published immediately upon acceptance

- cited in PubMed and archived on PubMed Central

- yours - you keep the copyright

Submit your manuscript here:

http://www.chemistrycentral.com/manuscript/

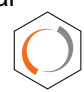

ChemistryCentral 